\title{
瀬戸内海における沿岸域生物多様性モニタリング手法の開発
}

\section{Development of littoral region biodiversity monitor technique in the Inland Sea}

\author{
徳岡誠人 ${ }^{1} \cdot$ 大森誠紀 ${ }^{2} \cdot$ 野村恒平 $^{3} \cdot$ 富田 智 $^{4} \cdot$ 上嶋英機 ${ }^{5}$
}

\section{Makoto TOKUOKA, Masanori OHMORI, Kohei NOMURA, Satoshi TOMIDA and Hideki UESHIMA}

\begin{abstract}
In the present study, the effectiveness of the Mapping method was verified. As a result, even the investigator who doesn't have expertise of the NPO group and the student, etc. by the proper move method can investigate, and the area was able to understand about $0.7 \mathrm{~km}^{2}$ wide-ranging one in two weeks. In addition, the adjustment with the water quality investigation result of the execution of the municipality was able to be taken, and acquired data was able to be judged to be a valid result.

On the other hand, because GIS is used about the management of data, it doesn't become the one that everyone can treat. Therefore, this Mapping method was devised for the possibility that the part was able to be borne to exist now at the time of having not established it by the monitoring methodology that continued in a mid/long term though future tasks were left in this part.
\end{abstract}

\section{1.はじめに}

近年，生態系機能の保全や生態系サービスの考え方に ついて広く浸透し始めている. 沿岸生態系から受ける各 種の享受を明確に評価するためには, 継続したモニタリ ングによって, その場の生物の多様性を把握することが 必要である. しかしながら, 現在中長期的かつ広範囲に モニタリングを行うことは難しい. その原因として,

1） 1 回当たりの調査に掛かる費用が高い

2）国や自治体が主導で行うことが多く，事業が終わる とその時点で途切れる

3）NPOを初めとする地元住民が主導としてモニタリン グを行うことが望まれるが, 現在の調査手法では専門 性が高く実施できない

などが挙げられる．特に簡便な調査手法については確立 しておらず, 定点調査や, ベルトトランセクト法のよう な線による空間的に断片的な海域生態系の把握が行われ ているのが実態である.また，これらの手法は，極めて 限られた範囲内における生息種を正確に把握することは できるが, 海岸の地形の変化や河川の流入等に伴う生態 系の変化を捉えることは困難である.ささに, 専門知識 を有する調査員が必要であり, 継続性という面で課題が 残る.

そこで本研究では, 地中海等で実際に行われているマ

\begin{tabular}{lll}
\hline 1 & 学修 & 日本ミクニヤ(株) 広島支店 支店長 \\
2 & 学修 & 日本ミクニヤ(株) 広島支店環境防災部 \\
3 & & 日本ミクニヤ(株) 広島支店環境防荻部 \\
4 & 正会員 & 日本ミクニヤ(株) 広島支店環境防災部 \\
5 正会員 & & 広島工業大学 大学院工学系研究科 環 \\
& & 境学専攻 教授
\end{tabular}

ッピング手法を改良し, 専門知識を有さない地元住民で も安価で簡便かつ広範囲に継続したモニタリングができ る手法の開発を目的として, 潮汐差の大きな瀬戸内海に おいて適応できる手法の開発を行ったので紹介する.

\section{2. 場所及び方法}

\section{（1）調査研究場所}

広島県厳島（以下，「宮島」とする。）は，広島湾の北 西部に位置している. また, 外周は, 約 $34 \mathrm{~km}$ あり, 瀬 戸内海の中では比較的大きな島と言える (図-1参照). 島の北部は, 大野瀬戸を挟んで本州と対面しており, 厳 島神社をはじめとする観光の盛んな地区で, 生活環境と 比較的近い環境といえる. 一方, 南部は広島湾湾口側に 面し, 原生林が茂っている地区である。 また, 道路整備 等が整っていないため, 人的影響が少ないといえる.

本研究は, 環境の違いによる生物の生息状況を把握す

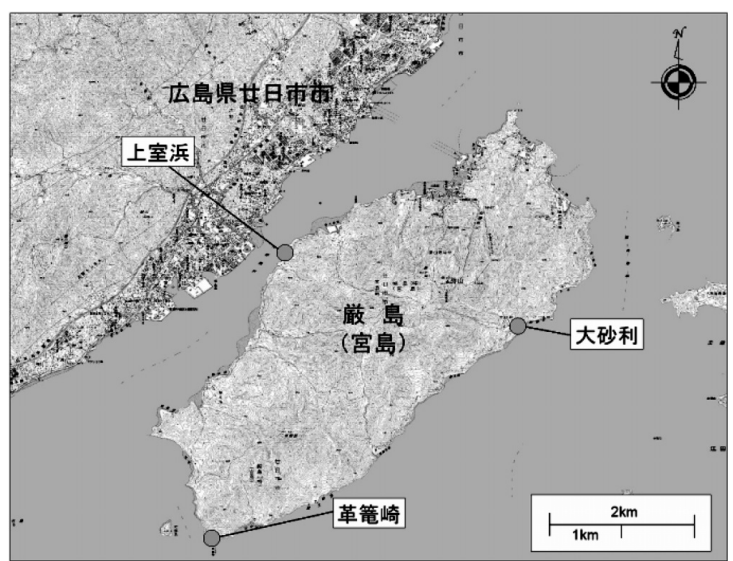

図-1 調查研究場所 
ることを目的の一つとしているため，前述のような条件 から環境変化が大きいと想定される宮島沿岸部全域を調 査研究場所として調査を行った。

\section{(2) 方法}

2003 年 6 月 17 日から 7 月 5 日にかけて宮島の潮間帯全 域において，生物モニタリング手法の開発及び現地施行 を実施した。調查は，上嶋らが1998年から継続して実施 しているマッピング手法（以下，従来のマッピング手法 とする）を一部改良して実施した．従来のマッピング手 法（特許第3861167号）とは，環境指標種となる潮間带 生物を 9 種（清浄海域指標種：カメノテ，オオヘビガイ, 污濁環境指標種：カサネカンザシ，イボニシ，アナアオ サ，マガキ，ムラサキイガイ，その他：アサリ，アマモ) とその他の情報として漂着ゴミおよび基質に絞り达み， 潮間带を最下部の基本水準面付近から潮間帯上部までの 範囲に調查員を配置することで，指標生物の生息密度を 広域かつ面的に調查を行う手法である。しかし，従来の マッピング手法は, 環境指標生物の個体数をカウントし て生物情報を取得するため，狭い範囲を定量的に把握す るには適しているが，迅速に広範囲を調查するには不適 切であった。

本研究では，広範囲の生物情報を迅速に入手する必要 があるため，生物情報の計測方法を簡易にする必要があ った。そこで，広島県が実施している基準（表-1参照） を用いた，本基準を用いて生物情報を取得することで， 広範囲な調査範囲を迅速に調査することができると考え られた。

調査を行う際には，調査員全員を集め事前のレクチャ 一により，調查対象生物に対する知識や，調查手法，ま た安全面に関する指導を約 30 分程度行った上で，各調査 場所へ移動した。1 調查箇所あたり 6〜10人程度で構成 された調査員が $20 \mathrm{~m}$ 進む毎に，上記生物の判定結果を管

表-1＼cjkstart環境指標生物の計数の定義

\begin{tabular}{|c|c|}
\hline 凡例 & 判定基準 \\
\hline- & :見られない \\
\hline rr & $\begin{array}{l}\text { : 非常に少ない } \\
\text { (海岸線 } 10 \mathrm{~m} \text { 当たり0.1単位以上 } 1 \text { 単位以下) }\end{array}$ \\
\hline $\mathrm{r}$ & $\begin{array}{l}\text { : 少ない } \\
\text { (海岸線 } 10 \mathrm{~m} \text { 当たり2単位以上10単位以下) }\end{array}$ \\
\hline $\mathrm{r}$ & $\begin{array}{l}\text { : 普通 } \\
\text { (海岸線 } 10 \mathrm{~m} \text { 当たり } 11 \text { 単位以上で } 1 \mathrm{~m}^{2} \text { 当たり被覆度 } \\
30 \% \text { 以下、または10単位以下) }\end{array}$ \\
\hline $\mathrm{c}$ & $\begin{array}{l}\text { :多い } \\
\left(1 \mathrm{~m}^{2} \text { 当たり被覆度 } 31 \% \text { 以上 } 50 \% \text { 以下、または } 11 \text { 単位 }\right. \\
\text { 以上 } 100 \text { 単位以下 })\end{array}$ \\
\hline $\mathrm{cc}$ & $\begin{array}{l}\text { : 非常に多い } \\
\left(1 \mathrm{~m}^{2} \text { 当たり被覆度 } 51 \% \text { 以、または } 101 \text { 単位以上 }\right)\end{array}$ \\
\hline
\end{tabular}

※単位は、単独性のものは個体数、群体性のものは群体数、賷生のものは 囊生体数とする。

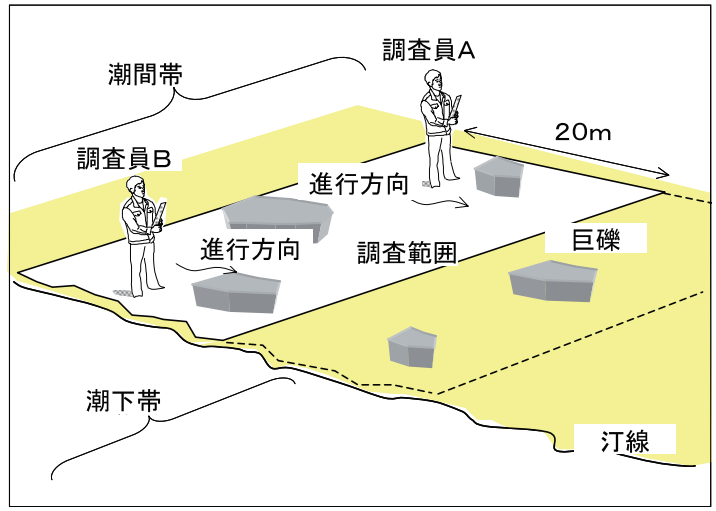

図-2 マッピング手法調査概要

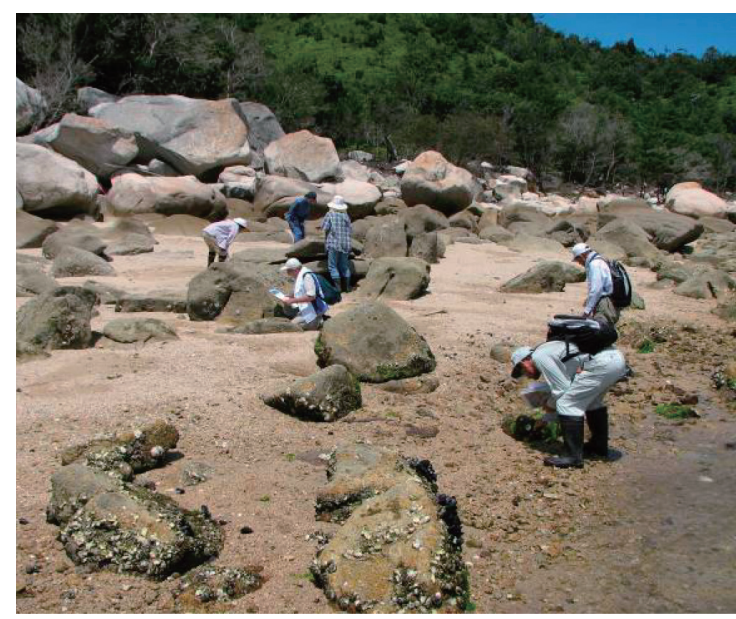

図-3 マッピング調査状況

理者に報告し，報告後次の $20 \mathrm{~m}$ の調査を行った。このプ ロセスを繰り返しながら調査範囲全域のモニタリングを 実施した（図-2,3 参照)。また，潮汐の影響により干出 範囲が変化するため，水中についてはウエットスーツを 着用した調查員がスキンダイブにより観察を行った。

\section{3. 検討項目}

前述した中長期的，継続的モニタリングを行うに当た っての課題を解決するため，またマッピング手法が有効 であるかどうかを判断するために，次の項目について検 証を行った。

\section{（1）取得データの妥当性の検証}

調査により得られた生物生息情報と，既存の水質情報 や地理的条件の相関より，専門知識を有さない調査員が 取得する生物情報が環境状態を捉えているかどうかを検 証した。

\section{（2）専門知識の有無に依らない調查の実施}

モニタリングを継続的に実施するためには，専門知識 を有さない地元住民でも実施可能な手法であることが重 
〈清浄環境指標種 : カメノテ>

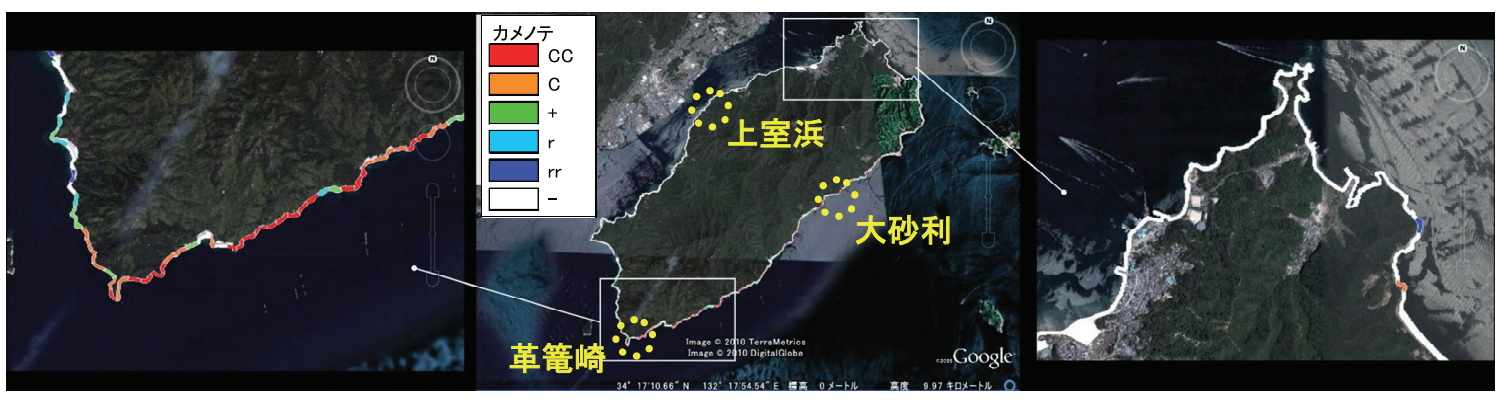

〈污濁環境指標種 : ムラサキイガイ>

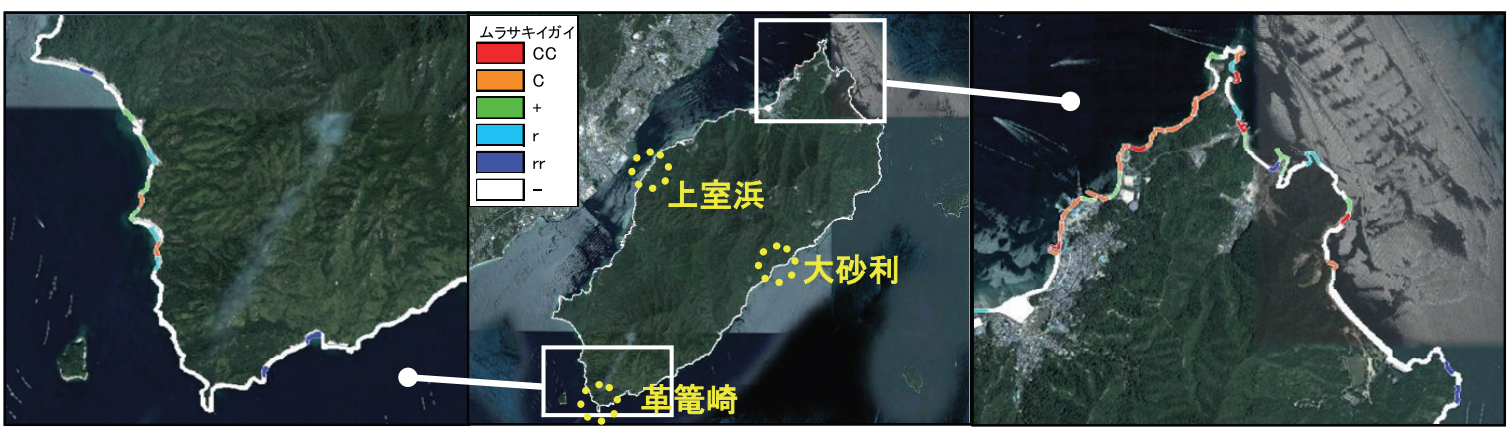

図-4 全域モニタリング結果の一例

要である. 従って, 環境指標生物を絞り込むことで, よ り簡便に調査が実施できるようにした。なお，環境指標 生物の絞込みに当たっては, 広島県の報告から広島湾に おける環境指標生物を抽出し, さらに潮間带において観 察しやすい生物に絞込みを行った。加えて, 本手法の有 効性を検証するため, 専門知識を有さないNPO団体や学 生といった専門知識を有さない方に協力を頂き, 調査を 実施した.

\section{4. 結果}

（1）取得データの妥当性について

全域モニタリング結果の一例（清浄環境指標種：カ メノテ，污濁環境指標種：ムラサキイガイ）を図-4に 示した。

環境指標生物は清浄海洋環境指標種と污濁海洋環境指 標種に大きく分類されるが, 調査の結果, 清浄海洋環境 指標種であるカメノテ，オオベビガイは南面に多くみら れ, 反対に污濁海洋環境指標種であるムラサキイガイ, アナアオサ, マガキ, カサネカンザシについては北面で 多く観察できた．この結果は，2003年6月〜8月に測定 された広域総合水質調査のCOD結果（北面： $3.1 \mathrm{mg} / 1$ $5.0 \mathrm{mg} / 1$, 南面 : $1.1 \mathrm{mg} / 1 \sim 3.0 \mathrm{mg} / 1)$ と一致した。また, 地理条件的にも人間生活からの距離から離れるほどカメ ノテをはじめとする清浄海洋環境指標種の生息密度が上
がり，反対にムラサキイガイをはじめとする污濁海洋環 境指標種の生息密度が下がっていた。

このことから，本調査で選定した環境指標生物及び調 査手法について環境状態を捉えるという意味で妥当であ ると言える。

（2）専門知識の有無に依らない調査の可能性について 本研究は, NPO団体や学生などの関心はあるが専門知 識を有さない調査員の協力のもと実施した. さらに, 事 前の教育等は行わず, 調査当日の説明と, 現地での 30 分 程度の簡単なレクチャーを実施することで, 環境状態を 捉えるだけのデー夕を取得することができた.

このことは，今後地元住民が自主的にかつ，簡便に調 査を行うことが可能となりうる手法であることを示唆し ている。

\section{（3）広範囲な調査の継続性について}

本調査は, 延長距離 $34 \mathrm{~km}$, 横断方向に $20 \mathrm{~m}$ 程度の調査 範囲（約 $0.7 \mathrm{~km}^{2} ）$ を 2 週間で実施するこができたが， 1 回 の調査に2 週間を掛けることは, 継続性の面での課題と なることが想定された。調査の継続性を担保するために は, 調査日数を削減する必要があり，1日で実施可能な 代表地区を設定する必要があったままた，代表地区の調 査を四季で実施し, 環境状態に大きな恋化が見られた際, 再度全域調査を実施することより環境を捉えることが可 能であると考えた。そこで，全域調査結果やその他地形 


\section{〈清浄環境指標種 : カメノテ>}
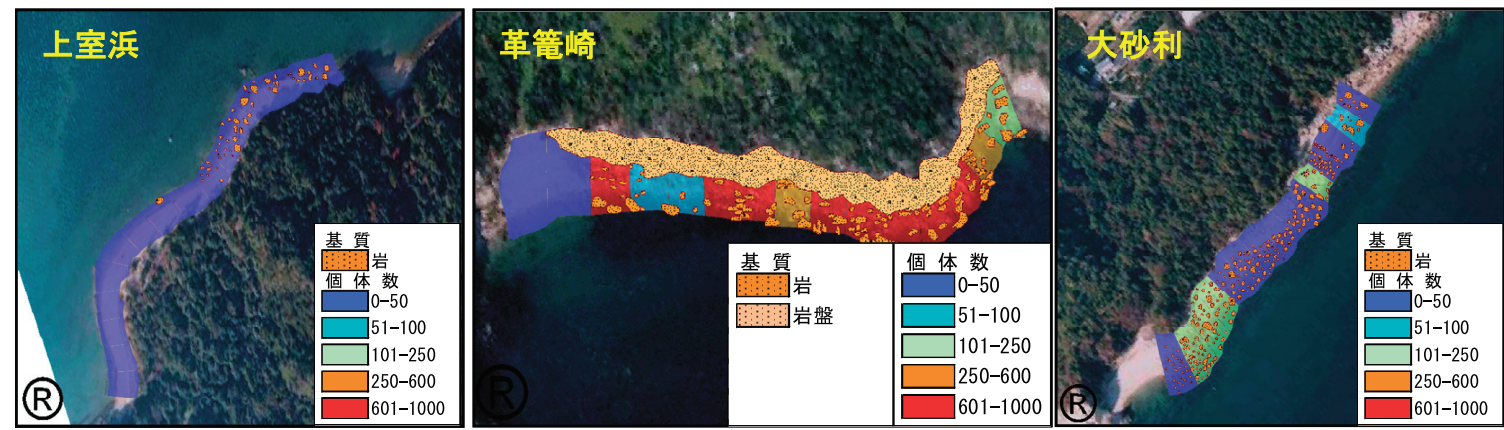

図-5 代表地区モニタリング結果の一例

条件（人的影響を受けやすい地区，影響を受けにくい地 区，中間的な位置づけの地区）から代表地区を 3 地区選 定し，1日で調査を終わらせることのできるように設定 した. なお, 調査延長距離は, 従来のマッピング手法と 同様に $300 \mathrm{~m}$ に設定した。

宮島沿岸部全域を評価するためには，設定した地区 で宮島沿岸部全域の環境状態を捉えることが可能であ ることが前提条件となるため，設定した代表地区の妥 当性について検討する必要があった。そこで，全域モ ニタリング結果と従来のマッピング手法を用いた代表 地区モニタリング結果を比較して整合がとれているか どうか検討した。

代表地区のモニタリング結果の一例（清浄環境指標 種：カメノテ）を図-5に示した。

代表地区のモニタリング結果をみると，カメノテは， 人的影響が少ない革篭崎で最も多く，次いで大砂利で多 く，人的影響が最も大きい上室浜で最も少ない結果が得 られた。この結果は，全域モニタリング結果の一例（図-4 参照）と同傾向を示しており，宮島沿岸部全域を評価す る代表地区として，有効であると考えられた。

以上のことから，代表点の設定を行うことで，簡易に 評価することができ，継続性の高いモニタリングが実施 可能であると考えられた。また，専門知識を有さない調 査員が特殊な機材を使用せずに実施でき，安価で広範囲 に調査が可能であるため，継続性のある調査方法である ことが確認された。

（4）誰もが閲覧，管理できるデータベースの構築につ いて

現地で得られた情報については，データベースによる 管理を行い，さらに誰もが見ることができるように可視 化を行ったデータベースの構築にはGISソフトの一つ であるArcView (ESRI社製) を用いた。さらに，より沉 用性の高いソフトでの可視化を行うためにGoogle earth (GOOGLE社製) にシェープファイルをインポートし，
誰もが簡単に閲覧できるシステムの構築を行った。しか し，これらの作業は誰もが行うことができるものではな い.そこで今後は，データの管理方法についてより簡易的 なものを開発，提案することが今後の課題である.

以上のことから，本手法は，定点調査，もしくはベル トトランセクト法に比べると沿岸域を広域かつ簡便に調 査を行うことができる。また，調査対象生物を絞り込む ことで，専門知識を有さない地元住民でも実施可能であ ることから，広く沿岸域の環境状態を把握することに対 して有効であることが明らかとなった。

\section{5. 今後の展望}

近年，中長期的モニタリングの重要性については，国 においても課題として挙げられており，環境省では「瀬 戸内海における超長期的生態系・景観モニタリング手法 の研究」として 2008 年から 2010 年まで研究が行われて いる。また，国土交通省においても「中長期的な展望に たった海岸保全検討会」が設置され2008年より検討が進 められている。いずれの事例からも，今後中長期的に， モニタリングを行うことで，これまで開発行為等によっ て破壊されてきた沿岸域環境を把握し, 保全・修復して いくか検討することが非常に重要であることが分かる.

一方，そのためのモニタリング手法については現在確 立しておらず，代表点や代表線でその場に生息する生物 を詳細に捉える，従来の海岸域調査手法で行われようと しているのが現状である.これらの手法は, 調査地点の詳 細な生物種や生息個体数を正確に把握することができる というメリットを有するものの，専門知識を有する専門 家が行うことが必要であり，費用面も含め，中長期的に 継続させることは困難であると言える.的確に環境状態を 捉えるためには，海岸地形や流入河川といった生物の生 息場の変化を併せて捉えることが必要であるため，より 広範囲に面として環境状態を把握できる手法が重要と考 える. 
今回開発したマッピング手法の特徵としては前述の通 り，1）広範囲を面的に調査することが可能である，2） 環境指標生物を定めることで，環境に関心はあるが専門 知識を有さない地域住民でもモニタリングが可能であ る，3）特殊な計測機器を用いないため, 安価での調査 が可能，という点が挙げられる.この手法によって得られ る結果は, 精密な調査精度は有さないが, 本研究内で試 行したとおり, NPO団体や学生といった専門知識を有さ ない調査員でも環境状態を把握することができ, その面 積は短期間で $0.7 \mathrm{~km}^{2}$ もの面積を捉えることができる手法 であることが分かった.このことから，本モニタリング手 法は将来的には自主的に, かつ長期的にモニタリングを 行うことができる手法になりうると考えられる.

一方，得られたデータの管理方法にはGISを用いたデ ータベースの構築を行っているが，これは誰もが取り扱 うことができるものではない.そこで今後は, デー夕の管 理方法についてより簡易的なものを開発, 提案すること が必要である。

最後に，本手法が普及することで将来的には各地域住 民が自らの海岸を自主的に，かつ継続的にモニタリング を行い, 環境変化を捉え, 沿岸域管理を推し進めてもら えれば幸いである。

\section{6. まとめ}

本研究では, マッピング手法の有効性に関して検証を 行った.その結果, 本手法によってNPO団体や学生など の専門知識を有さない調査員でも調査を行うことがで き，かつその面積は 2 週間で約 $0.7 \mathrm{~km}^{2}$ もの広範囲を把握 することができた.さらに，得られたデータについては， 自治体の実施する水質調査結果や地形条件との整合が取
れており，妥当な結果であると判断できた.一方，データ の管理についてはGISを用いているため, 誰もが扱える ものにはなっていない.従って, この部分に今後の課題は 残すものの, 中長期的に継続したモニタリング手法が確 立していない現在, 本マッピング手法はその一端を担え る可能性があると考えられた。

謝辞：調査を行うに当たって，ご協力いただきました広 島大学内サークル The Earthの皆様, 広島工業大学環境学 部環境デザイン学科の学生の皆様に感謝いたします.

\section{参 考 文 献}

上嶋英機, 三好孝治, 中本 修, 池本康洋, 能野あやな, 藤 崎奈緒美（2008）：沿岸域の生態系・景観モニタリング手 法の開発と環境学習への応用〜電子野帳によるモニタリ ング手法の試行〜, 日本沿岸域学会研究討論会 2008 講演 概要集, No.21,181p.

上嶋英機, 大森誠紀, 藤崎奈緒美, 土屋正隆, 市村 康 （2008）：沿岸域環境モニタリング調查法の研究，海洋調査 技術学会 第20回研究成果発表会講演要旨集, pp. 54-55.

農林水産省, 国土交通省（2007）：中長期的な展望に立った海 岸保全検討会, pp.16-17.

環境省中国四国地方事務所（2008）: 平成 19年度瀬戸内海におけ る超長期的生態系・景観モニタリング手法の研究, $157 \mathrm{p}$.

環境省中国四国地方事務所 (2009)：平成20年度瀬戸内海におけ る超長期的生態系・景観モニタリング手法の研究, $157 \mathrm{p}$.

環境省中国四国地方事務所 (2010) : 平成 21 年度瀬戸内海におけ る超長期的生態系・景観モニタリング手法の研究, $260 \mathrm{p}$.

広島県環境保健センター (2001) : 広島県の海岸生物モニタリ ング調査報告書, $63 \mathrm{p}$.

LIONS CLUB (1999) : Mer Vivante 1999/8 edition, 94p.

LIONS CLUB (2002) : Mer Vivante 2002-11 ${ }^{\mathrm{e}}$ Edition, $121 \mathrm{p}$.

特 許

上沜英機, 召古裕士，田中秀宜，小松輝久 (3861167号) 